\title{
INDUSTRIAL FLOW DISTRIBUTION IMPROVEMENT BASED ON CFD ANALYSIS IN A PELLETIZING FURNACE AT SAMARCO*
}

\begin{abstract}
Samarco produces high quality iron ore pellets processed in straight grate furnaces. This process is essential in order to obtain adequate mechanical strength to the pellet transportation and operation in the reduction reactors. All mechanical properties of the agglomerates are obtained during the stage of firing where the slag and sintering bond happens, thus it is a decisive step to improve the pellet quality. Therefore, the velocity distribution of gas flow within this zone must have homogeneous and even velocity distribution. Hence, it was developed a mathematical CFD model to characterize the gas flow in the burning zone, applying the equations of conservation of momentum, mass and energy and an uneven flow distribution was identified and the gas velocity analyzed and validated through experimental data. On the other hand, on the present paper, an improved firing zone burner were developed and industrially implemented in a way to mitigate the uneven flow pattern detected aided by CFD. Different burner designs, based on CFD analysis, were experimented in order to succeed on the aggressive condition. The combustion was investigated and burner efficiency evaluated and compared with the simulation purposed.
\end{abstract}

Keywords: Modeling; CFD; Pelletizing; Packed beds.

Engenheiro Metalurgista, MSc, Eng., Samarco Mineração, Anchieta, ES, Brasil.

Engenheiro Metalurgista, Phd, Professor, UFMG, Belo Horizonte, MG, Brasil.

Engenheiro Metalurgista, Eng., Samarco Mineração, Anchieta, ES, Brasil.

Técnico de Processo, Samarco Mineração, Anchieta, ES, Brasil.

* Contribuição técnica ao 44 Seminário de Redução de Minério de Ferro e Matérias-primas, 15ํ Simpósio Brasileiro de Minério de Ferro e 2o Simpósio Brasileiro de Aglomeração de Minério de Ferro, 15 a 18 de setembro de 2014, Belo Horizonte, MG, Brasil. 


\section{INTRODUCTION}

One of the strategic objects of Samarco Mineração S/A is to "ensure quality products and services" [1]. The iron ore pellet quality is given when mechanical resistance is added to the agglomerates. This property is obtained by thermal treatment of the pellets in Travelling Grate furnace. In order to achieve this goal the furnaces processes the pellets in three steps: drying, firing and cooling. According to Meyer [2], all properties of the agglomerates are obtained during firing, and therefore the step is crucial to ensure the quality of the pellet.

Travelling Grate furnaces are thermal equipment based in intense heat convection transport. Through recovery of the heated air due to the cooling of the pellets at the discharge of the furnace, firing of the new agglomerates is performed, through adding heat to the pre-heated air via burners positioned along the firing zone. Despite of the importance for the quality of the product, temperature thermocouple placed above the pellet bed has been indicating unbalanced gas flow along the firing zone, additionally thermographic images of furnace discharge have shown a large temperature distribution along the bed cross section. Uneven air flow distribution may lead to higher variability on the final physical quality of agglomerates.

The decrease on pellet quality increases the risk of degradation during transport [3]. Additionally, in industrial practice, the irregular hot air flow distribution along the cross section of the furnace may generate premature and non-uniform mechanical parts wearing specially in the firing zone where the highest temperature came up.

Additionally, fluid dynamic and geometric factors may be associated with non-regular profile of the heated air flow, which is unwanted to the process. The geometric asymmetry of furnace windboxes, which conduct the air flow from the firing zone to the exhaust fan, seems also to be critical and is also pointed out as the reason of the preferential wearing of the pallet car at the south side.

\section{MATERIALS AND METHODS}

\subsection{Firing Zone Fluidynamic Mathematical Modelling}

In order to accomplish the understanding of the flow pattern across the furnace, a numerical code based on finite elements method was applied [4] for solving continuity and Average Reynolds Navier-Stokes equations (RANS). The energy conservation equation was also included on the solver. The study was conducted with resources from LaSiP - Process Simulation Laboratory, in the Department of Metallurgy of the Engineering School at UFMG. The discretization of the fluid domain was carried out through a mesh of 118,225 elements (the mesh independence test showed less than $2 \%$ variation with double elements which was accepted). The combustion was taken into account based on the assumption of non-reactive approach injecting a stream of combustion products $\left(\mathrm{CO}_{2}, \mathrm{H}_{2} \mathrm{O}, \mathrm{N}_{2}\right.$ and $\left.\mathrm{O}_{2}\right)$ at the adiabatic flame temperature, considering a multicomponent flow. The flow regime was considered permanent. This latter simplification was done to minimize the computational cost due to high mesh refinement achieved. It may fit the industrial practice as the gas flow is roughly fully developed crossing the pellet beds, however, the pellet bed movement is transient regarding the furnace production line. This consideration is valid regarding the purpose is the flow profile analysis of the gases (many studies have evaluated the pellet bed temperature profile after Thurlby et al. [5]. The $\mathrm{K}-\varepsilon$ model turbulence better adapted to the experimental data and it is a

* Contribuição técnica ao 44 Seminário de Redução de Minério de Ferro e Matérias-primas, $15^{\circ}$ Simpósio Brasileiro de Minério de Ferro e 2o Simpósio Brasileiro de Aglomeração de Minério de Ferro, 15 a 18 de setembro de 2014, Belo Horizonte, MG, Brasil. 
model largely used in industrial cases according to Seshadri et al. [6]. One more assumption needed to the travelling grate furnace is the effect that the porous bed generates on pressure drop of the fluid through the furnace. This effect may be modelled adding a source term on the momentum equation (ANSYS, 2010). This source term can be defined by equation 1 which is similarly to the Ergun's equation for pressure drop in the particle bed [7].

$$
-\frac{\partial \mathrm{p}}{\partial \mathrm{x}_{\mathrm{i}}}=\frac{\mu}{\mathrm{K}_{\text {perm }}} \mathrm{U}_{\mathrm{i}}+\mathrm{K}_{\text {loss }} \frac{\rho}{2} \mathrm{U}_{\mathrm{i}}|\mathrm{U}|
$$

Where, $\mathrm{K}_{\text {perm }}=\frac{1}{150} \frac{\varphi d^{2}}{\frac{(1-\varepsilon)^{2}}{\varepsilon^{3}}} \quad$ e $\mathrm{K}_{\text {loss }}=1,75 \frac{\frac{(1-\varepsilon)}{\varepsilon^{3}}}{\varphi d}$

\section{RESULTS AND DISCUSSION}

\subsection{Fluid Flow at Firing Zone Characterization}

It is shown in Figure 1 the velocity and the flow pattern of gases in the region of the firing zone. The velocity contours shows the existence of areas with high velocities, especially close to the side grate bars and burner chamber.

As a matter of fact, this map also highlighted the effect on the inlet flow from the burner of the downcomer, which generates a deflection in flames leading to a change in velocity pattern inside the combustion chamber. It seems to influence the entire velocity profile in the firing zone of the furnace. According to Athayde et al. [1], this effect can increase the risk of obstruction of the combustion chamber due to accumulation of particles carried out through the downcomers on the combustion chamber bottom.

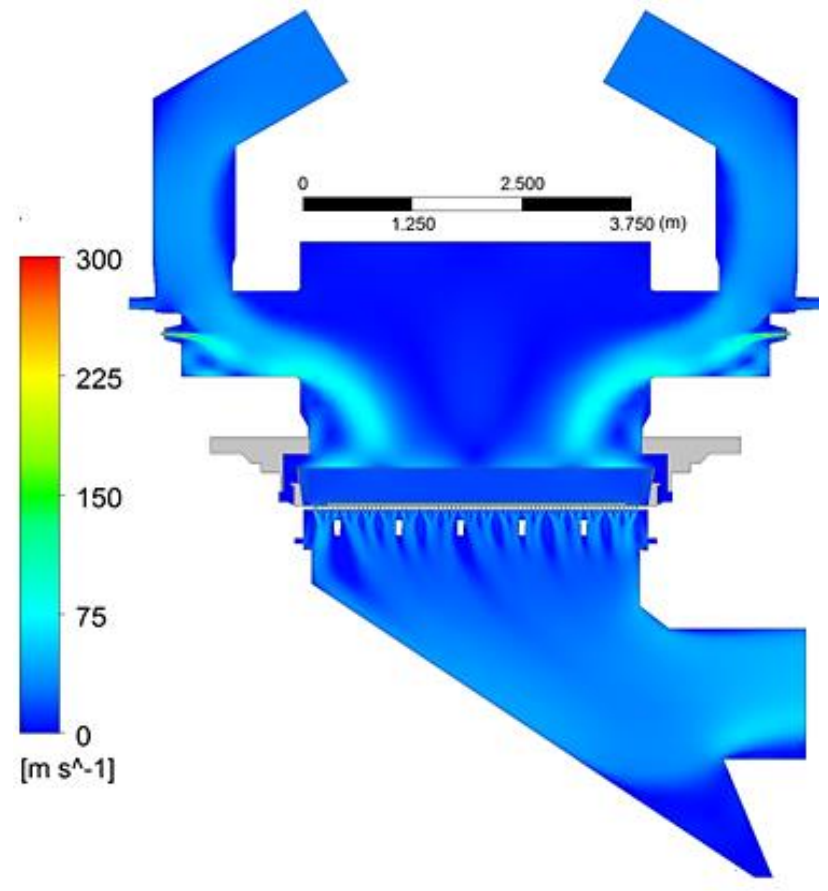

Figure 1 - Contours velocity inside the firing furnace zone pelletizing [1].

* Contribuição técnica ao 44 Seminário de Redução de Minério de Ferro e Matérias-primas, 15ㅇ Simpósio Brasileiro de Minério de Ferro e 2o Simpósio Brasileiro de Aglomeração de Minério de Ferro, 15 a 18 de setembro de 2014, Belo Horizonte, MG, Brasil. 
The flame deflection on the burner chamber is mainly due the high momentum rate from the hot air stream coming from the downcomer crossing the natural gas jet from the burner nozzle. The Figure 3 shows through a frontal picture of the burner chamber where the flame tail is shift downwards, as expected, based on the model observations (left hand side of Figure 2).

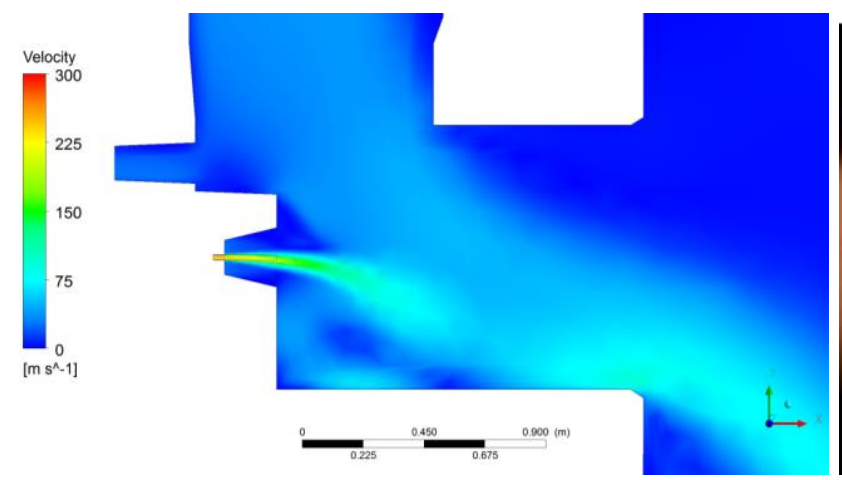

(a)

Figure 2: (a) Velocity Contour inside burner chamber (b) Frontal Image of the burner chamber.

The burner chamber outlet velocity profile (red line at upper right corner detail in Figure 3) indicate along the chamber length there are flow recirculation, on the upper chamber part where horizontal negative velocity have been seen. This effect may lead to an increase in temperature at this region and refractory wearing as observed in industrial practice.

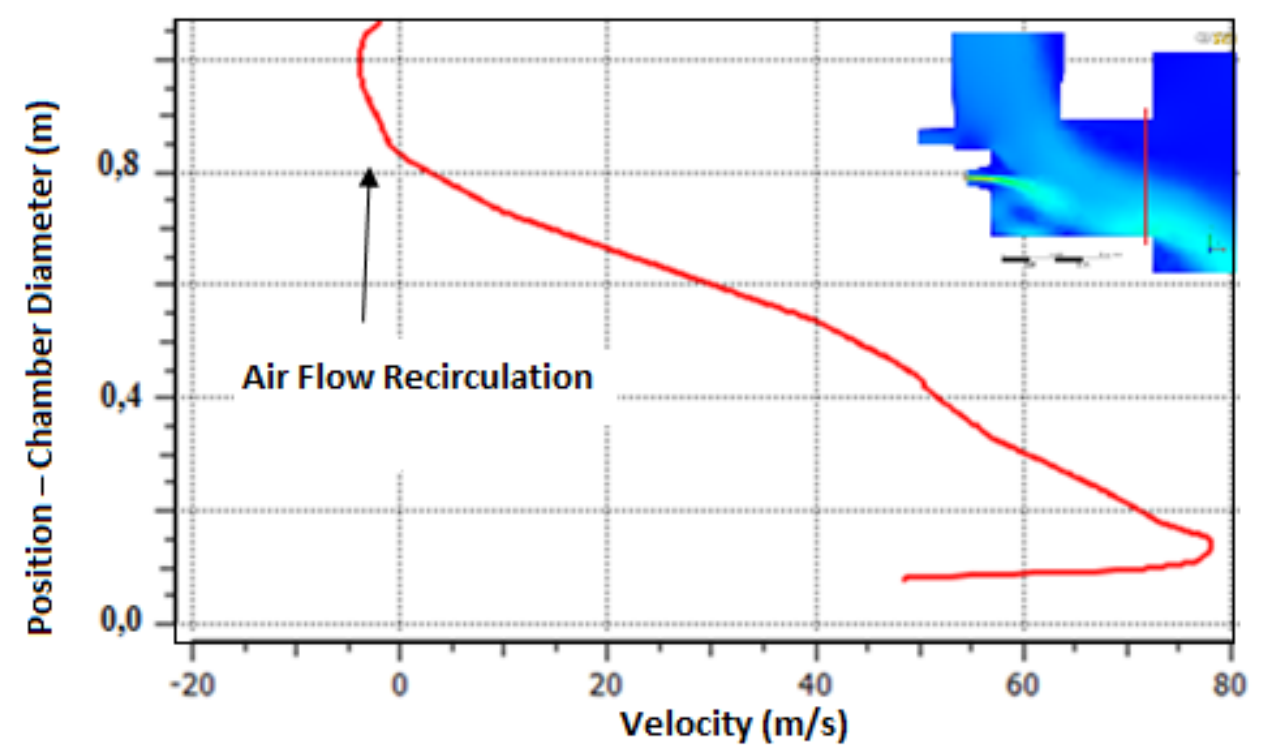

Figure 3 - Velocity distribution (horizontal component) along the burner chamber height $(10 \mathrm{~cm}$ before the outlet line).

\subsection{Natural Gas Injection Point Improvement}

The impact of the momentum flow of the hot air coming from the downcomer in deflection of the natural gas jet needed to be improved. Therefore, the proper fuel injection point was investigated in this paper, it was then evaluating the impact region of the hot air. The results of the study is summarized in the velocity contour plot at

* Contribuição técnica ao 44 Seminário de Redução de Minério de Ferro e Matérias-primas, 15ㅇ Simpósio Brasileiro de Minério de Ferro e 2ํ Simpósio Brasileiro de Aglomeração de Minério de Ferro, 15 a 18 de setembro de 2014, Belo Horizonte, MG, Brasil. 
Figure 4, the plot shows that the new jet setup is strongly inclined than the actual setup, however the simulation also remark that this happen closer to the jet discharge. However, even with this more intense tilt, loss of jet velocity occurs further and inside furnace hood and after burner chamber outlet line. It causes the velocity profile to move forward more toward the center of the furnace.
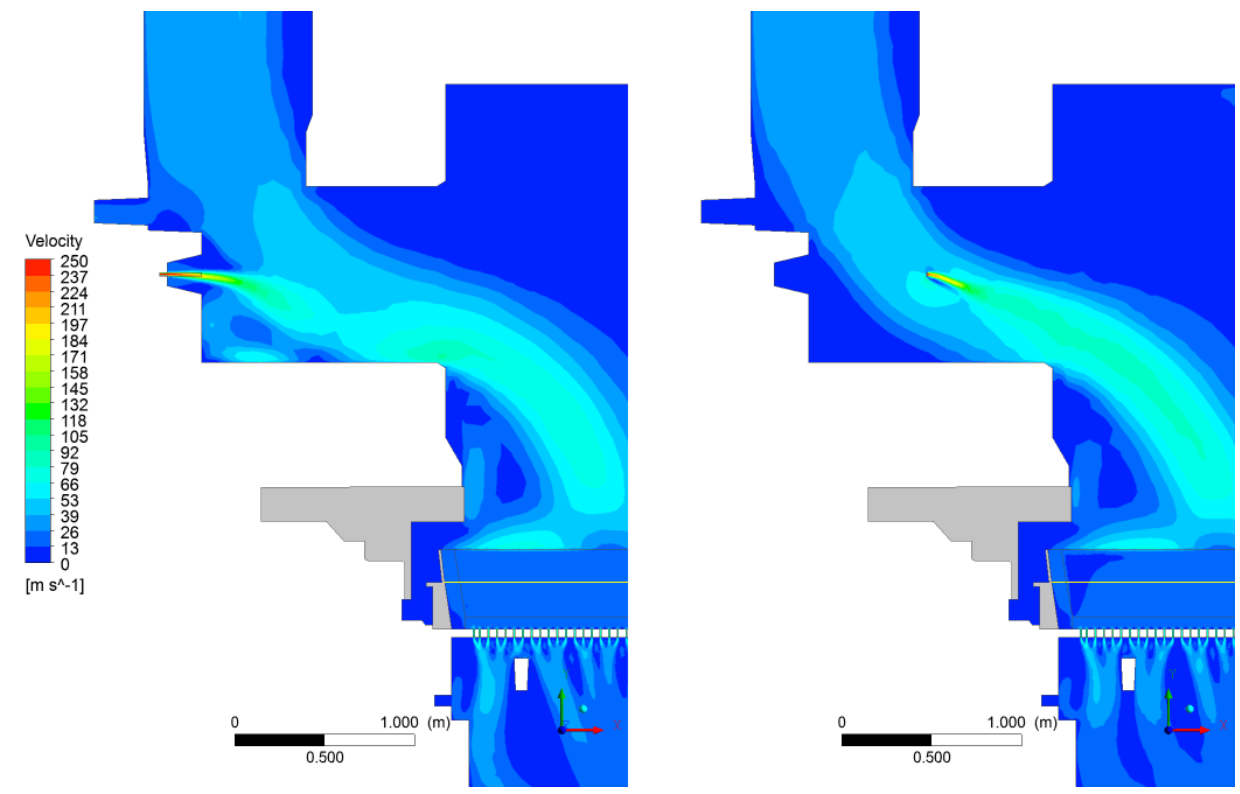

Figure 4 - Velocity profile at the burner chamber: Actual Set up (left), New Setup (Right).

The resultant effect of this modification was directly applied over the pellet bed. The "impact point" moves forward over the transversal axis of the furnace nearer to the furnace center line. It was remarkable the average velocity reduction of $18 \%$ at the side hearth layer of the pallet car which can be closer visualized at the Figure 5 velocity plot. The improved velocity distribution along the pellet bed has the potential to improve the heat exchanged between the air flow and pellet, hence reducing the wear pattern seen at the side grate bars as the flow flux goes properly in the needed areas. It is important to highlight that the main reason for the side hearth layer is to thermally protect the pallet car side wall, then heat flow within this area is, in principle, highly undesired.

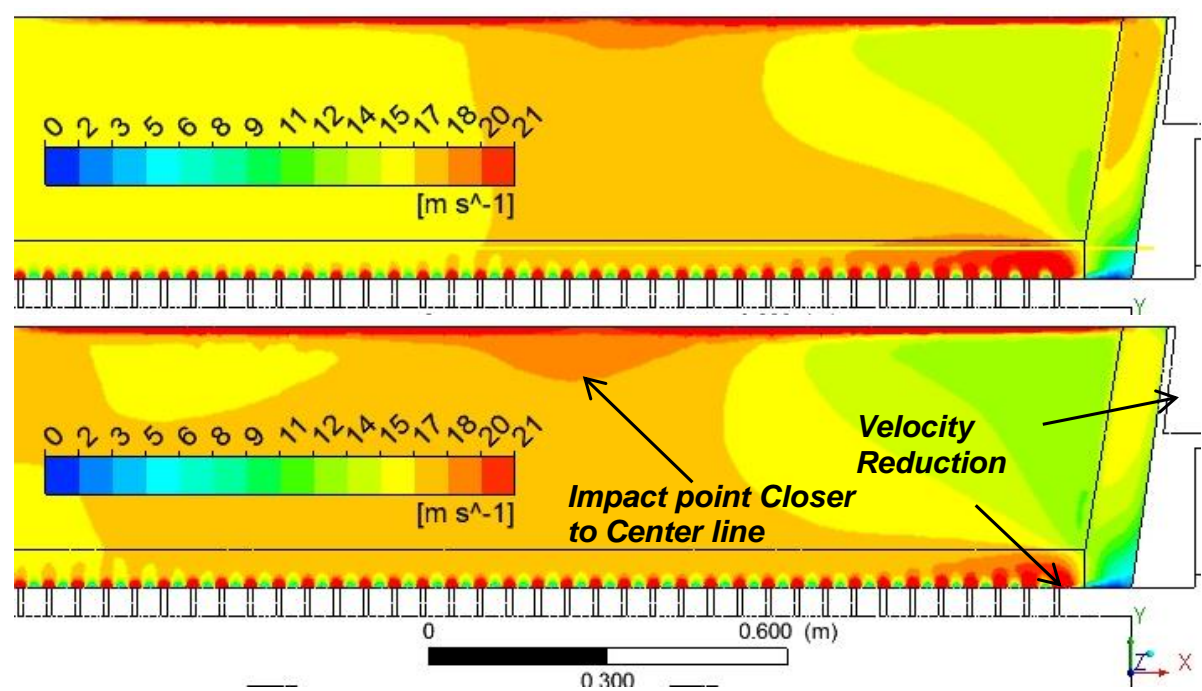

Figure 5 - Velocity Profile in the pellet bed: Actual Setup (Upper), New Setup (Bottom).

* Contribuição técnica ao 44 Seminário de Redução de Minério de Ferro e Matérias-primas, 15ㅇ Simpósio Brasileiro de Minério de Ferro e 2ํ Simpósio Brasileiro de Aglomeração de Minério de Ferro, 15 a 18 de setembro de 2014, Belo Horizonte, MG, Brasil. 
The fuel jet deflection reduces inside the combustion chamber; it leads to an equivalent improvement in the temperature profile inside the hood of the firing zone. The Figure 6 shows the projection of the jet into the furnace and a greater temperature homogenization within the firing zone. However, the recirculation in the central part of the hood temperature increased (also observed in the actual set up) and warm up the whole upper hood, however not more than $100^{\circ} \mathrm{C}$.
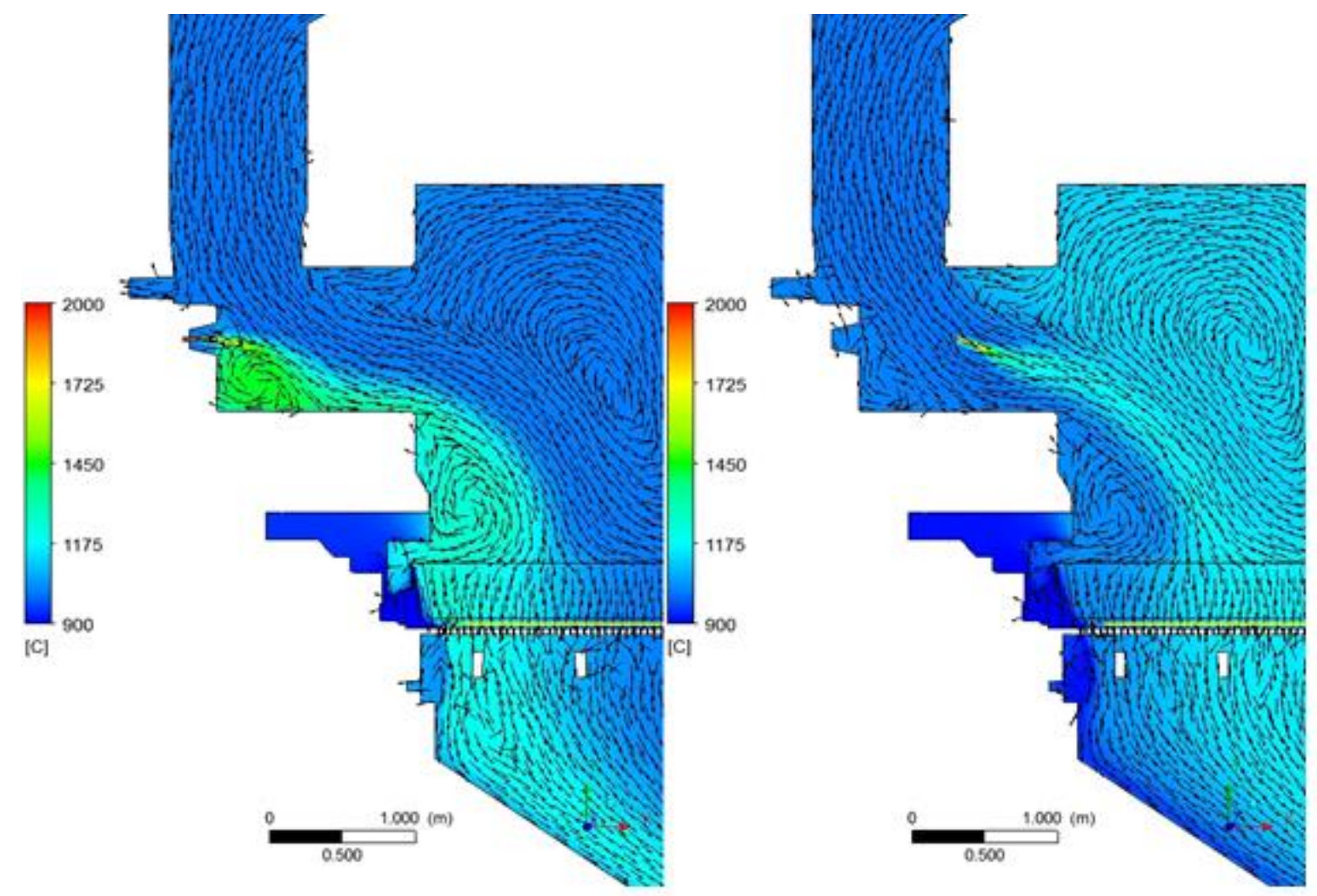

Figure 6 - Temperature profile at the burner chamber: Actual Setup (left), New Setup (Right).

The recirculation within the combustion chamber still exists in this new setup established and it traps some hot gases from the hood thus increasing the temperature at the upper part of the chamber. However, the new setup reduced the average temperature through the whole combustion chamber. It is an expected result of this modification a positive impact on the bottom refractory life due to the reduction in average temperature as highlighted in Figure 7. At the upper part of the combustion chamber, the temperature increased due to the hood gas trapped at the air flow recirculation at the upper part of the chamber, but it kept the combustion chamber below $1150^{\circ} \mathrm{C}$. It should be noted that the greater uniformity and even distribution of gases in furnaces can lead to reduction of the effective thermal power of the burners as the heat is then better distributed along the bed of pellets [8].

* Contribuição técnica ao $44^{\circ}$ Seminário de Redução de Minério de Ferro e Matérias-primas, 15ㅇ Simpósio Brasileiro de Minério de Ferro e 2ํ Simpósio Brasileiro de Aglomeração de Minério de Ferro, 15 a 18 de setembro de 2014, Belo Horizonte, MG, Brasil. 


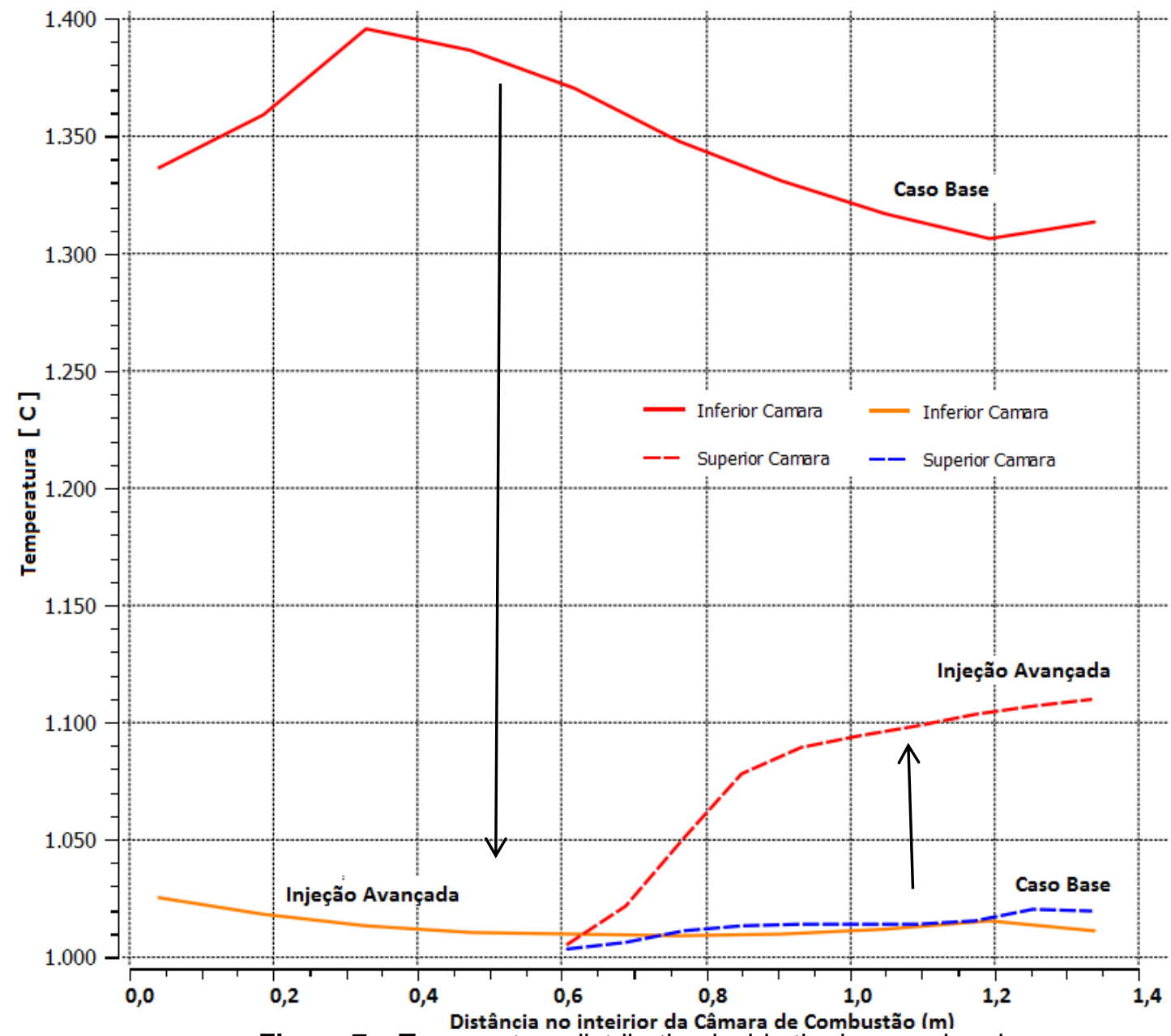

Figure 7 - Temperature distribution inside the burner chamber.

At the pallet car sides, the temperature was reduced, especially on the sides walls, compared with the actual case. The Figure 8 shows the improvement in the pellets temperature profile. This new profile compared to the actual case generates an increase of $130^{\circ} \mathrm{C}$ in the pallet car center (strongly potential for reducing degradation of the pellets), and also a reduction of around $300^{\circ} \mathrm{C}$ in the region of the side grate bars. This effect leads to reduction in variability of physical quality of the pellets. It can be estimated an improvement in the condition of grate cars due to this better air flow distribution.

* Contribuição técnica ao 44ํㅗㄴ Seminário de Redução de Minério de Ferro e Matérias-primas, $15^{\circ}$ Simpósio Brasileiro de Minério de Ferro e 2o Simpósio Brasileiro de Aglomeração de Minério de Ferro, 15 a 18 de setembro de 2014, Belo Horizonte, MG, Brasil. 

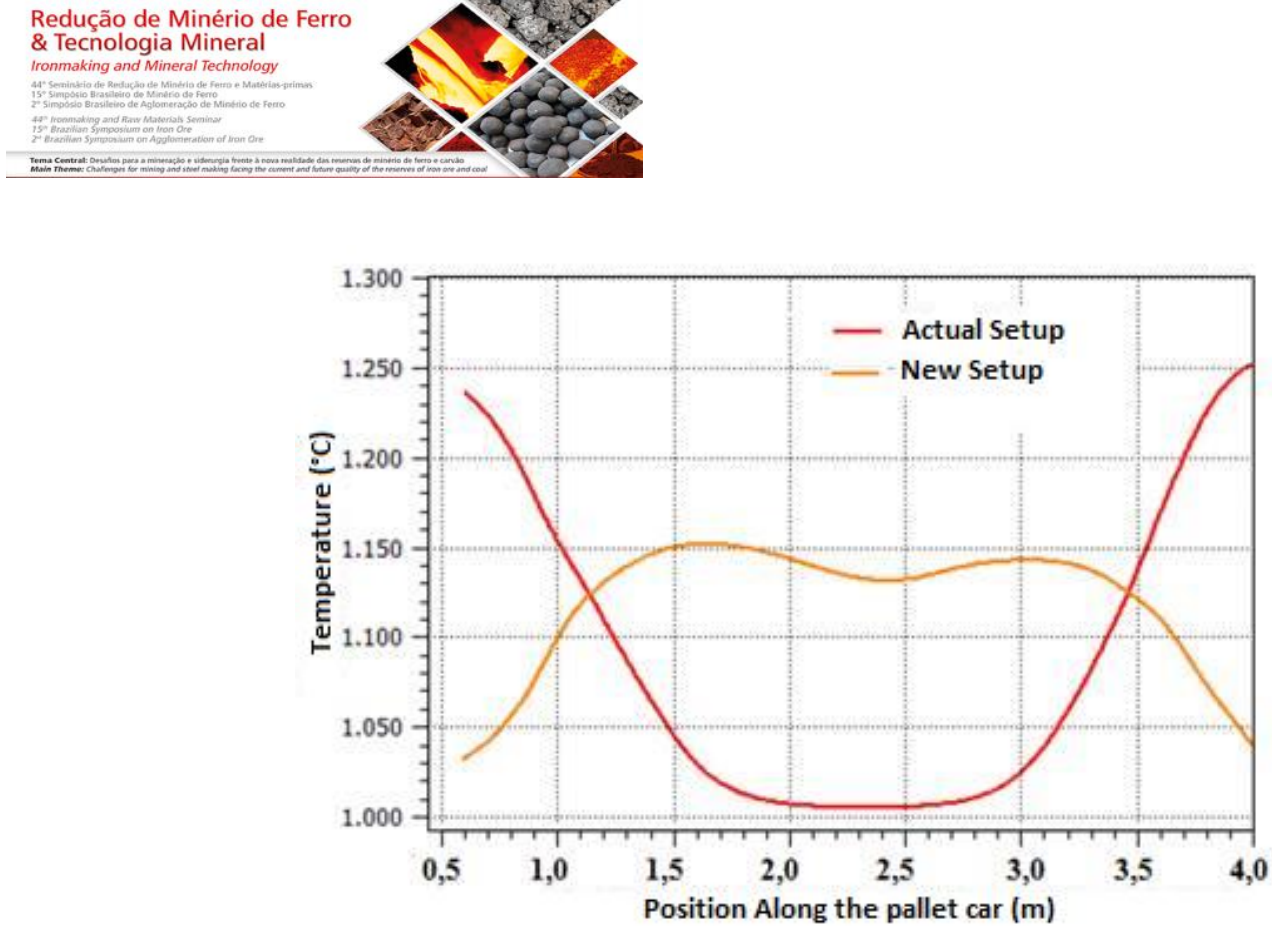

Figure 8 - Temperature distribution along the pellet bed for the actual setup and the new setup (Pellet bed height quote $=0,2 \mathrm{~m}$ ).

\section{CONCLUSION}

The new fuel injection setup evaluated had a highly positive and good potential for industrial application. The descriptive statistics shows that it was possible to reduce the peak temperature in the bed of pellets around 38\%. Furthermore, it was identified a $6 \%$ reduction in average velocity within the hearth side layer which allowed the air goes straight to center of the pallet car. It was obtained an increase about $1.5 \%$ in the average bed temperature of pellet (which could decrease the overall furnace heat input). An additional improvement was the reduction in the temperature variability range across the pellet bed from $249^{\circ} \mathrm{C}$ to $22^{\circ} \mathrm{C}$ which allows significant gains in profile thermal homogenization.

\section{REFERENCES}

1 Athayde M, Tavares RP, Nunes SF, Fonseca CM. Avaliação da distribuição de gases em forno de pelotização da Samarco Mineração através de CFD e validação experimental, $43^{\circ}$ Seminário de Redução de Minério de Ferro e Matérias-Primas \& $14^{\circ}$ Simpósio Brasileiro de Minério de Ferro \& 1o Simpósio Brasileiro de Aglomeração de Minério de Ferro, 2013

2 Meyer K. Pelletizing of Iron Ores, Düsseldorf: Springer-Verlag mbH, 1980, p 205.

3 Nunes SF. Influência da Carga Circulante do Pelotamento na Qualidade Física das Pelotas Cruas e Queimadas da Samarco Mineração, Ouro Preto: REDEMAT-UFOP, 2007, 133p (Dissertação, Mestrado em Engenharia Metalúrgica).

4 Patankar SV. Numerical heat transfer and fluid flow. Washington: McGraw Hill Book Company, 1980, 197p

5 Thurlby JA, Batterham RJ, Turner RE. Development and validation of a mathematical model for the moving grate induration of iron ore pellets, International Journal of Mineral Processing, 1979; 6(1): 43-64.

6 Seshadri V, Tavares RP, Silva CA, Silva IA. Fenômenos de transporte: fundamentos e aplicações nas Eng. Metalurgica e de Materiais, São Paulo: ABM, 2010. P 798.

7 Niven KR. Physical insight into the Ergun and Wen \& Yu equations for fluid Flow in packed and fluidised beds, Chemical Engineering Science, Vol 57, p 527 - 534, Outubro 2002

8 Batterham RJ. Modeling the Development of Strength in Pellets, Metallurgical Transactions B, Londres, Vol 17B, Setembro 1986.

* Contribuição técnica ao $44^{\circ}$ Seminário de Redução de Minério de Ferro e Matérias-primas, 15o Simpósio Brasileiro de Minério de Ferro e 2o Simpósio Brasileiro de Aglomeração de Minério de Ferro, 15 a 18 de setembro de 2014, Belo Horizonte, MG, Brasil. 